\title{
Planktonic foraminifera from the Pliocene Coralline Crag of Suffolk, Eastern England
}

\author{
D. G. JENKINS ${ }^{1}$, D. CURRY ${ }^{2}$, B. M. FUNNELL ${ }^{3}$ \& J. E. WHITTAKER ${ }^{4}$ \\ ${ }^{1}$ Department of Earth Sciences, Open University, Milton Keynes MK7 6AA \\ "Mallard Creek", Spinney Lane. Itchenor, West Sussex PO20 7DJ \\ ${ }^{3}$ School of Environmental Sciences. University of East Anglia, Norwich NR4 7TJ \\ ${ }^{4}$ Department of Palaeontology, British Museum (Nat. Hist.), London SW7 5BD
}

\begin{abstract}
Nine species of planktonic foraminifera have recently been identified from the Coralline Crag of Suffolk, Eastern England. Stratigraphically important species include Globorotalia puncticulata (Deshayes) and Neogloboquadrina atlantica (Berggren) whose joint ranges, based on evidence from the North Atlantic, indicate an age for the deposit of between c. 4.2 and $2.3 \mathrm{Ma}$; other published evidence suggests that it may not be younger than c. 3.4 Ma. The low planktonic foraminiferal species diversity is interpreted as being due to a combination of factors, including the shallow water nature of the Coralline Crag, which would preclude deeper water species of planktonic foraminifera, and the possibility that the source of the fauna was from relatively high latitudes of the North Atlantic via the northern entrance to the North Sea. The planktonic foraminifera recorded indicate that the water temperature of the sea was within the range $10-18^{\circ} \mathrm{C}$.

The Coralline Crag contains very rich Lusitanian faunas of gastropod and bivalve molluscs, bryozoans, ostracods and benthic foraminifera.
\end{abstract}

\section{INTRODUCTION}

Foraminifera from the Coralline Crag, a richly fossiliferous shallow marine deposit, which adjoins and underlies part of the southern North Sea (Fig. 1), were first recorded and systematically illustrated by Jones $e t$ al. (1866). At that time the only indigenous planktonic specimens were recorded as Globigerina bulloides d'Orbigny.

A number of slides in the foraminiferal collections of the British Museum (Natural History) contain planktonic foraminifera from the Coralline Crag: H. B. Brady (P 38449; Sutton Knoll), H. B. Brady (P 38436; Sudbourne Park), C. D. Ovey (ex P 38547; Sudbourne Park), F. Möckler (P 16385, P 16387, P 16388; Gedgrave Cliff), W. K. Parker \& T. R. Jones (P 48315. P 48356; Sutton Knoll) (for localities, see Fig. 1; for occurrences, see Table 1). All these slides are labelled "Globigerina bulloides d'Orbigny", but in fact contain exclusively Neogloboquadrina atlantica (Berggren). which is now found to be the commonest species in the Coralline Crag. The actual specimen illustated by Jones et al. $(1866$, pl. 2, figs. 1, 2) cannot be located with certainty, but it is probably one of a suite of specimens from Sutton Knoll in the Parker \& Jones Collection; it is undoubtedly referable to $N$. atlantica, and in possessing a high spire, is similar to that illustrated by us in Pl. 2 , figs. $5-7$.

Subsequent work by Carter $(1951 ; 1957)$. Wilkinson (1980) and Doppert (1985) have concentrated almost solely on the benthic foraminifera. The most recent work is by Hodgson \& Funnell (1986) who have re-interpreted the benthic foraminifera, particularly from a palaeoecological viewpoint, and some reference is made in their paper to the quantitative occurrence of planktonic species formally described herein.

King (1983) recorded and illustrated the following species of planktonic foraminifera from the Pliocene of the North Sea: Globorotalia inflata (d'Orbigny), $G$. puncticulata (Deshayes), Neogloboquadrina atlantica (Berggren) and $N$. pachyderma (Ehrenberg); also $N$. atlantica from the Coralline Crag. From the evidence of the benthic foraminifera King $(1983,14)$ suggested that the Coralline Crag was coeval with his (benthic) Early Pliocene Zone NSB 14 and from the presence of sinistrally coiled $N$. atlantica he indicated a correlation with his (planktonic) Late Miocene-Early Pliocene Zone NSP 15 (see Table 2).

This paper describes and illustrates the planktonic foraminifera obtained from samples collected by D. Curry at Sutton Knoll and Gedgrave Cliff and by N. J. Morris at Ramsholt Cliff. See Fig. 1 for localities.

The samples from Sutton Knoll (grid ref. TM 305 441), Ramsholt Cliff (TM 298 428) and Gedgrave Cliff (TM 398 486) are all thought to be from the Silty Sand Facies (Facies A) of the Coralline Crag (Mathers et al., 1984). This represents a lower energy environment than much of the Coralline Crag, and molluscs and bryozoans from it are well preserved. This facies probably corresponds to the Lower Division (15m) (Prestwich, 1871) of the total $(25 \mathrm{~m})$ thickness of the Coralline Crag (see Mathers et al., 1984). Doppert 
(1985) has suggested that the benthic foraminifera from these localities may indicate slightly older deposits than the remainder of the Coralline Crag, corresponding to the lower part, rather than the main part of the Netherlands FB Zone. This is consistent with the correlation of the Coralline Crag with the Early Pliocene NSB 14 Zone of King (1983). Andrew \& West (1977) equated the samples from the Orford Borehole (depth 33-38 feet), on palynological evidence to the Brunssumian (Early Pliocene) Stage of the Netherlands succession.

Planktonic foraminiferal species are rare in the Coralline Crag when compared with the benthic foraminifera. The dominant species, $N$. atlantica, has a strong robust test and is also found in the higher energy Facies B (Mathers et al., 1984) at localities near Sudbourne, including Crag Farm (see Fig. 1); planktonic foraminifera of Facies $\mathrm{C}$ are too badly preserved, however, to be specifically identifiable (G. E. Hodgson, pers. comm.). All other species, with the exception of $G$. puncticulata, are very rare, with only a few specimens of most and with single specimens only of Orbulina universa d'Orbigny and Turborotalita cf. quinqueloba (Natland). The SEM photographs in Plates 1 and 2 show that the tests are well preserved.

\section{TAXONOMIC NOTES}

Synonymies are confined to the original citation, redescription of type material, important name changes, and King's (1983) records from the North Sea. All figured specimens are housed in the Protozoa Section, Department of Palaeontology, British

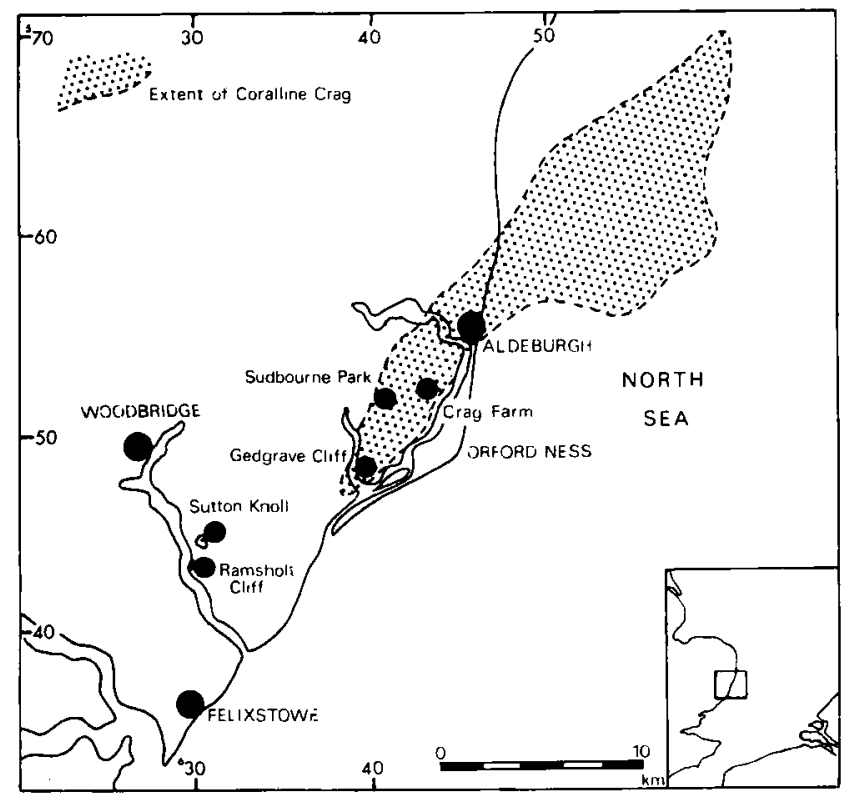

Fig. 1. Distribution of the Coralline Crag. showing localities mentioned in the text.
Museum (Natural History), London, registration nos. P 51974-P 51983.

\section{Globigerina brayi Wiesner}

(Pl. 1, figs. 12, 13)

1884 Globigerina sp. Brady: 603, pl. 82, figs. 8, 9.

1931 Globigerina bradyi Wiesner: 133.

1960 Globigerina bradyi Wiesner; Banner \& Blow: 5 pl. 3, figs. 1, 2 (lectotype).

Remarks. As already discussed by Jenkins et al. (1986), we consider this species to be distinct from $G$. uvula (Ehrenberg). G. bradyi ranges from the Early Oligocene to the Pleistocene (Bolli, 1957; Jenkins, 1966, 1967) and is also recorded in the Recent (Brady, 1884; Wiesner, 1931). In the Coralline Crag deposits this small, high spired species is very rare and has only been found at Ramsholt Cliff.

\section{Globigerina bulloides d'Orbigny}

(Pl. 1, figs. 1-3)

1791 "Polym. Tuberosa et Globulifera" Soldani (pars): 117, pl. 123, fig. 0 only (vas 251).

1826 Globigerina bulloides d'Orbigny: 227, list no. 1, modèle no. 76 only.

1960 Globigerina bulloides d'Orbigny; Banner \& Blow: 3, pl. 1, figs. 1a-c (lectotype).

Remarks. This is the only species recorded by Jones $e t$ al. (1866) but all their specimens (Brit. Mus. (Nat. Hist.) Collections) are referable to Neogloboquadrina atlantica (Berggren) (see p. 1 herein). The true $G$. bulloides does occur in the present material (Sutton Knoll and Gedgrave Cliff), but it is very rare. $G$. bulloides s.l. is a long ranging species (see Jenkins et al., 1986).

\section{Globigerinita glutinata Egger \\ (PI. 1, figs. 7, 8)}

1893 Globigerina glutinata Egger: 371, pl. 13, figs. 19-21.

1962 Globigerinta glutinata (Egger); Parker: 246, pl. 9, figs. 1-16.

Remarks. The illustrated specimen has a broken-off bulla. The species has only been found at Ramsholt Cliff. A few small specimens, however, were also found at Sutton Knoll and Gedgrave Cliff with no trace of a bulla, and may belong to the possibly related species $C$. juvenilis Bolli (see comments in Jenkins et al., 1986); they are not illustrated.

\section{Globorotalia puncticulata (Deshayes)}

(PI. 1, figs. 14-16)

1826

Globigerina punctulata d'Orbigny: 277 (nomen nudum).

1832 Globigerina puncticulata Deshayes: 170.

1960) Globigerina puncticulata Deshayes; Banner \& Blow: 15, pl. 5, figs. 7a-c (lectotype). 
Table 1. Occurrence of planktonic foraminifera in the Coralline Crag.

$$
\begin{aligned}
\mathbf{P} & =\text { present } \\
\mathrm{R} & =\text { rare } \\
\mathrm{VR} & =\text { very rare } \\
? & =\text { uncertain identification }
\end{aligned}
$$

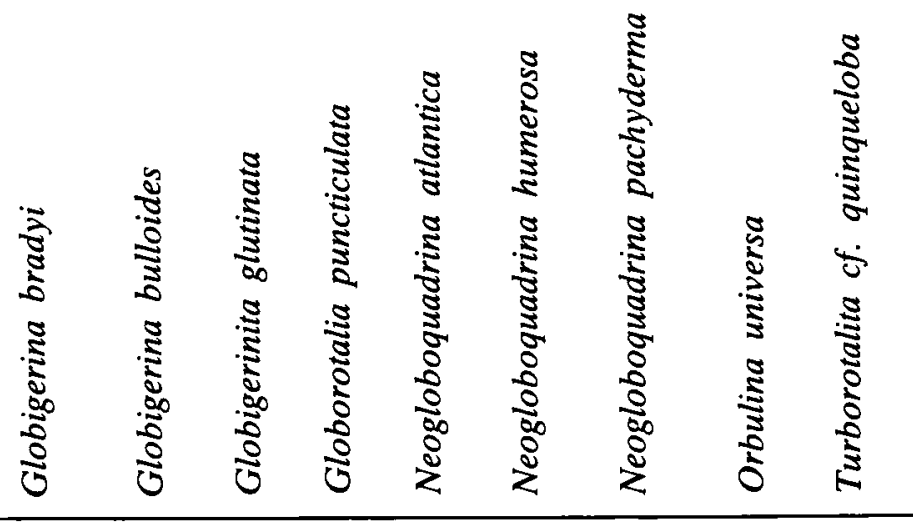

Facies C

(Skeletal sand)
Crag Pit Nursery,

Aldeburgh (planktonics poorly preserved and unidentifiable)
Facies B

\begin{tabular}{|c|c|c|c|c|c|c|c|c|c|c|}
\hline & Gedgrave Cliff & & VR & $?$ & & $\mathbf{P}$ & $\mathbf{R}$ & $\mathbf{R}$ & VR & \\
\hline \multirow{3}{*}{$\begin{array}{l}\text { Facies A } \\
\text { (Silty sand) }\end{array}$} & Sutton Knoll & & VR & $?$ & $\mathbf{P}$ & $\mathbf{P}$ & & $\mathbf{R}$ & & \\
\hline & Ramsholt Cliff & VR & & $\mathbf{R}$ & & $\mathbf{P}$ & & $\mathbf{R}$ & & ? \\
\hline & Orford Borehole & & & & & $\mathbf{P}$ & & & & \\
\hline
\end{tabular}

(Sandwave)
Crag Farm $\quad P$

Sudbourne Park P
1983 Globorotalia puncticulata (Deshayes); King: 36, pl. 6, figs. 14,15 .

Remarks. There is good evidence that $G$. puncticulata evolved from $G$. sphericomiozea Walters in the Early Pliocene (Jenkins, 1975; Scott, 1980; Kennett \& Srinivasan, 1983) but Malmgren \& Kennett (1981) regard its ancestor as $G$. conomiozea Kennett. This evolution took place in the mid-high latitudes of the oceans of the Southern Hemisphere, but the evolutionary event has not been recorded either in the North Atlantic, where $G$. puncticulata made a late entry in the Early Pliocene (Poore, 1978), or in the tropicalsubtropical belt such as the eastern equatorial Pacific (Jenkins \& Orr, 1972).

At around the Early/Late Pliocene boundary, in the mid-latitudes of the S.W. Pacific, $G$. puncticulata evolved into $G$. inflata (d'Orbigny), and in the North Atlantic Poore (1978) reports that there is an overlap in their stratigraphic ranges in the lower part of the Late Pliocene of DSDP Site 410 (Fig. 2). Weaver (1986), on the other hand, states that there is no overlap in the ranges of the two species in the upper part of the Late Pliocene of the DSDP Sites drilled on Legs 80 (Site
548), 81 (Site 552A) and 94 (Sites 606-611)(Fig. 2). In the North Sea, King (1983) also recorded the extinction of $G$. puncticulata just before the first appearance of $G$. inflata near the Early/Late Pliocene boundary. In the Coralline Crag, G. puncticulata is present but is unaccompanied by its descendent species, $G$. inflata.

One of the main morphological differences between $G$. puncticulata and $G$. inflata is the number of chambers in the final whorl. From counts made on S. W. Pacific populations, Malmgren \& Kennett (1981) showed that this varies from a mean of 4.0 to 3.6 in $G$. puncticulata, in contrast to figures of 3.6 to 3.25 for $G$. inflata, the mean in each case decreasing with time from the earliest occurrence (first number) to the latest (second number). Of the 35 specimens of $G$. puncticulata obtained from the Sutton Knoll sample the following range of chamber counts in the final whorl was made: one specimen ( 4.5 chambers), 24 (4.0), eight (3.75) and two (3.5), giving a mean of 3.9 chambers in the final whorl.

In order to assess whether Malmgren \& Kennett's (1981) figures hold true for populations in the North Atlantic, and are thus applicable to the Coralline Crag, 
an analysis was made of the chamber numbers in the final whorl of $G$. puncticulata at DSDP Site 609B (Fig. 2); 100 specimens were examined from each of four samples, one at the base of its stratigraphic range, one in the middle and two at the top. In the lowermost sample (Core Catcher 29; Early Pliocene), the mean number of chambers in the final whorl was 4.05 , in the middle sample (Core Catcher 24) it was 3.99 and in the two top samples (Core Catcher 20 and 19; Late Pliocene) the figures were 3.97 and 3.93 , respectively. Thus the results from both Site 609B and from the Coralline Crag would place these populations within the lowermost part of the stratigraphic range of $G$. puncticulata as given by Malmgren \& Kennett (1981) for the S. W. Pacific. It therefore appears that in the North Atlantic this species was either undergoing a much slower rate of morphological change or it may not have been connected with the evolutionary lineage which led to $G$. inflata as reported from the Southern Hemisphere. Some evidence is provided for this latter hypothesis by Weaver (1986) who has reported a cryptogenic appearance of $G$. inflata at a number of DSDP Sites in the North Atlantic after the extinction of $G$. puncticulata.

Neogloboquadrina atlantica (Berggren)

(Pl. 2, figs. 5-10)

1972 Globigerina atlantica Berggren: 972, pl. 1, figs. $1-7$, pl. 2, figs. 5-8.

1974 Neogloboquadrina atlantica (Berggren); Poore \& Berggren: 108, pl. 3, figs. 11, 12.

1983 Neogloboquadrina atlantica (Berggren); King: 36 , pl. 6, figs. $26,27$.

Remarks. Poore (1978) recorded dextrally coiled $N$. atlantica in the Late Miocene in the DSDP Sites 407 and 408 , with a change to sinistral coiling at the base of the Pliocene and its extinction more or less at the Pliocene/ Quaternary boundary. Weaver (1986) has a similar range but shows its extinction within the Late Pliocene (Table 2).

Specimens of $N$. atlantica were first recorded in the Coralline Crag by King (1983) but in the historical collections in the British Museum (Natural History) from Sutton, Gedgrave and localities around Sudbourne, it was previously identified as Globigerina bulloides d'Orbigny (see p. 2, herein). In the present study it was found at Ramsholt Cliff, Gedgrave Cliff and Sutton Knoll; it also occurs in the Coralline Crag samples from the Orford borehole in which Andrews \& West (1977) identified pollen which they equated with the Brunssumian (Early Pliocene) pollen stage of the Dutch succession. In all the material so far examined by us the coiling direction is sinistral.

A proportion of specimens of $N$. atlantica in the Coralline Crag are high spired (Pl. 2, figs. 5-7), a feature which does not appear to have been previously recorded; similar specimens, however, occur in a topotype sample from DSDP Site 116 and have been seen by one of us (D. G. J.).

Neogloboquadrina humerosa (Takayanagi \& Saito) (PI. 1, figs. 4-6)

1962 Globorotalia humerosa Takayanagi \& Saito: 78. pl. 28, figs. $1,2$.

1976 Neogloboquadrina humerosa (Takayanagi \& Saito); Srinivasan \& Kennett: 335, pl. 6, figs. $1-13$.

1983 Neogloboquadrina ex gr. acostaensis (Blow)/ humerosa (Takayanagi \& Saito); King: 36, pl. 6, figs. 24,25 .

Remarks. $N$. humerosa was originally described from a warm-water area and had 6-7 chambers in the final whorl, but in the cooler mid-latitudes there is a reduction to 5-6 chambers. Kennett \& Srinivasan (1980) recognised this as phenotypic variation and Kennett \& Srinivasan (1983: 196) suggested a latitudinal cline with end members $N$. humerosa (warm) and $N$. subcretacea (Lomnicki) (temperate). Unfortunately, there is a taxonomic problem associated with the latter name and the types of the replacement taxon, $N$. dutertrei (d'Orbigny) blowi Rögl \& Bolli, as reillustrated in Bolli \& Saunders $(1985,211$, figs. 27, 28), appear to be morphologically different from $N$. humer$o s a$. If a name is required for the 5-6 chambered form,

\section{Explanation of Plate 1}

All specimens are $\times 125$

Figs. 1-3. Globigerina bulloides d'Orbigny. Spiral, edge and umbilical views, P 51974. From Sutton Knoll.

Figs. 4-6. Neogloboquadrina humerosa (Takayanagi \& Saito). Spiral, edge and umbilical views, P 51975. From Gedgrave Cliff.

Figs. 7, 8. Globigerinita glutinata (Egger). Spiral and umbilical view; the bulla has broken off. P 51976. From Ramsholt Cliff.

Figs. 9-11. Turborotalita cf. quinqueloba (Natland). Spiral, edge and umbilical views, P 51977. From Ramsholt Cliff. Figs. 12, 13. Globigerina bradyi Wiesner. Two side views, P 51978. From Ramsholt Cliff.

Figs. 14-16. Globorotalia puncticulata (Deshayes). Spiral, edge and umbilical views, P 51979. From Sutton Knoll. 


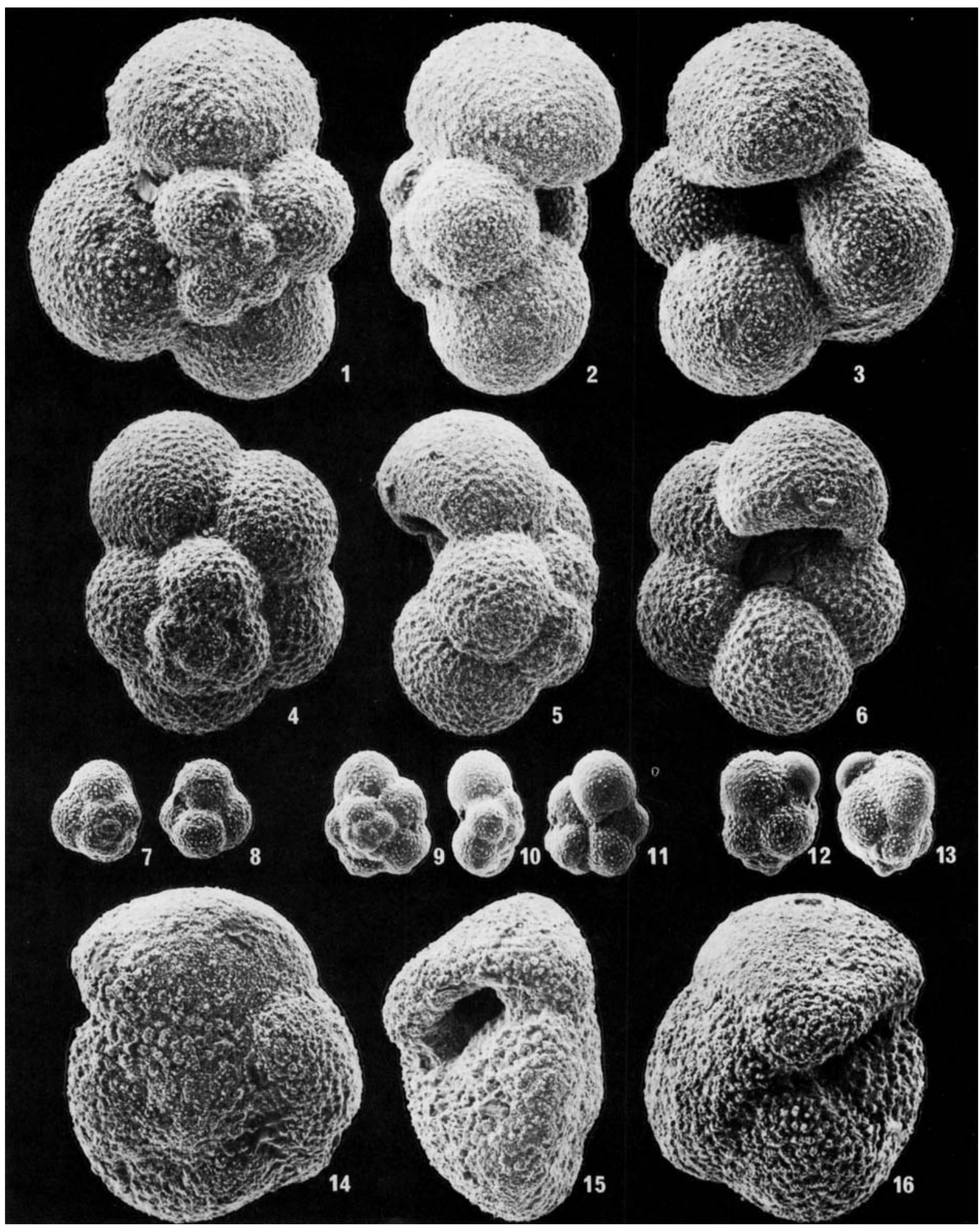




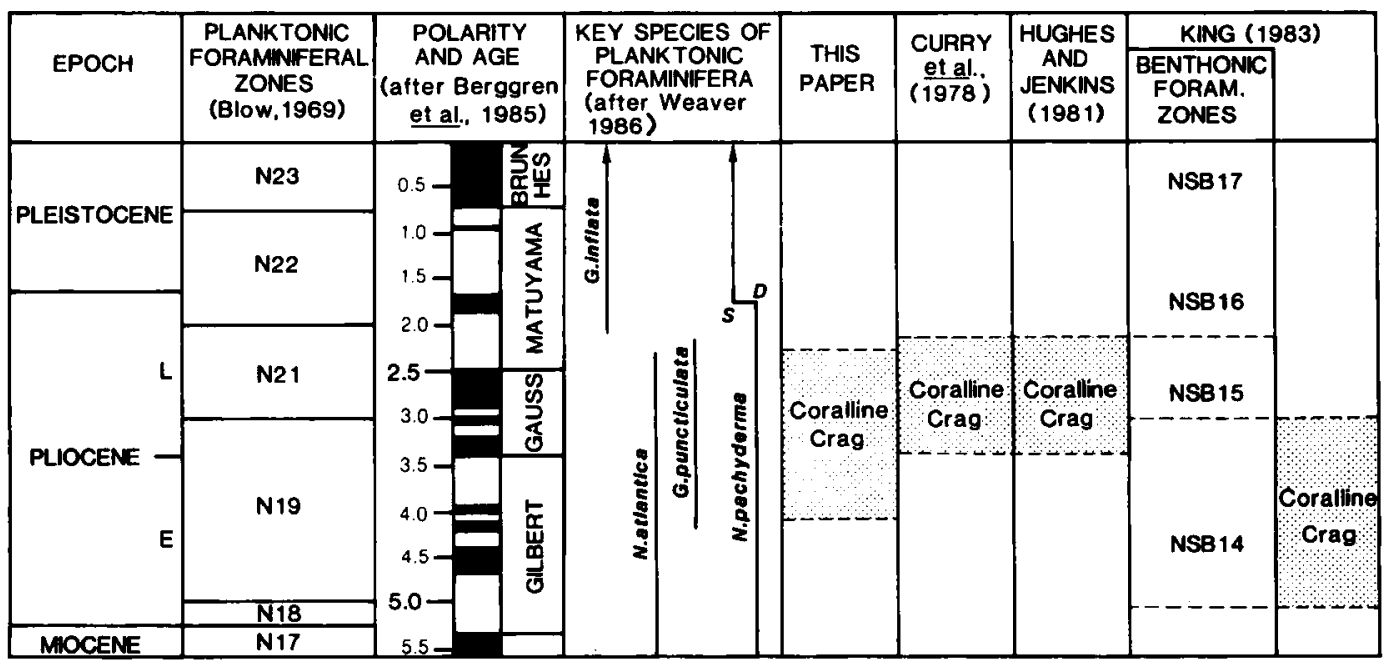

Table 2. Ranges of several key species of planktonic foraminifera (after Weaver, 1986) plotted against Berggren $e t$ al.'s (1985) time scale, and showing the stratigraphic position of the Coralline Crag according to various authors.

then $N$. praehumerosa (Natori) is available, but here we take the view that it is not necessary.

The cooler water variant of $N$. humerosa is distingished from $N$. atlantica (Berggren) in having 5-6, rather than 4 chambers in the final whorl; $N$. acostaensis has a lipped aperture and $N$. dutertrei (d'Orbigny) has an umbilical tooth, neither features being in $N$. humerosa. In the North Atlantic $N$. humerosa has a range of Late Miocene to Late Pliocene (Poore, 1978). It was only found in the Coralline Crag at the Gedgrave Cliff locality, where it is rare.

\section{Neogloboquadrina pachyderma (Ehrenberg)}

(PI. 2, figs. 1-3)

1861 Aristerospira pachyderma Ehrenberg: 303.

1873 Aristerospira pachyderma Ehrenberg; Ehrenberg: pl. 1, fig. 4.

1962 Globigerina pachyderma (Ehrenberg); Parker: 224, pl. 1, figs. 26-35; pl. 2, figs. 1-6.

1983 Neogloboquadrina pachyderma (Ehrenberg); King: 36, pl. 6, figs. 23, 29.

Remarks. Specimens of $N$. pachyderma are much smaller and rarer than $N$. atlantica (Berggren) in the Coralline Crag; the populations are mixed sinistrally and dextrally coiled specimens, compared with exclusively sinistrally coiled $N$. atlantica. Specimens were found at Ramsholt Cliff, Gedgrave Cliff and Sutton Knoll.

\section{Orbulina universa d'Orbigny}

(P1. 2, fig. 4)

1839 Orbulina universa d'Orbigny: 3 , pl. 1 , fig. 1. Remarks. Only one specimen was found in the Coralline Crag samples, from Gedgrave Cliff.
Turborotalita cf. quinqueloba (Natland)

(P1. 1, figs. 9-11)

cf. 1938 Globigerina quinqueloba Natland: 149, pl. 6, fig. 7.

cf. 1984 Turborotalita quinqueloba (Natland); Holmes: 101 et seq., pl. 3, figs. 9-11.

Remarks. One possible specimen was found at Ramsholt Cliff.

\section{PALAEOECOLOGY}

The duration of the Early Pliocene has been estimated at $1.8 \mathrm{Ma}$, from 5.2 to $3.4 \mathrm{Ma}$ (Berggren et al., 1985) (Table 2). It was a time of high planktonic foraminiferal diversity in the North Atlantic. At DSDP Sites 407 and 408 (lat. 63 $3^{\circ}$ N) (see Fig. 2) Poore (1978) recorded 25 and 22 species respectively and at the warmer Site $410\left(\right.$ lat. $45^{\circ} \mathrm{N}$ ) there were no less than 45 species present. The low species diversity in the Early Pliocene sediments of the North Sea area, with five species listed by King (1983) and nine species found by us in the Coralline Crag (lat. $52^{\circ} 30^{\prime}-53^{\circ} 00^{\prime} \mathrm{N}$ ), is therefore relatively anomalous.

It is possible that the English Channel was not open in the Early Pliocene (Pomerol, 1982) and the low diversity fauna of the North Sea area was only connected to the North Atlantic via the northern passage (at about lat. $60^{\circ} \mathrm{N}$ ). Comparison would therefore be expected with the fauna obtained from DSDP Sites 407 and 408 (Table 2; Fig. 2). Indeed, examination of the faunas from within the stratigraphic range of Globorotalia puncticulata (Deshayes) at these sites reveals a diversity of only 16 and 19 species, respectively, in the upper part of the Early Pliocene. On the other hand, the southern North Sea is sufficiently remote from open oceanic waters to account for the 


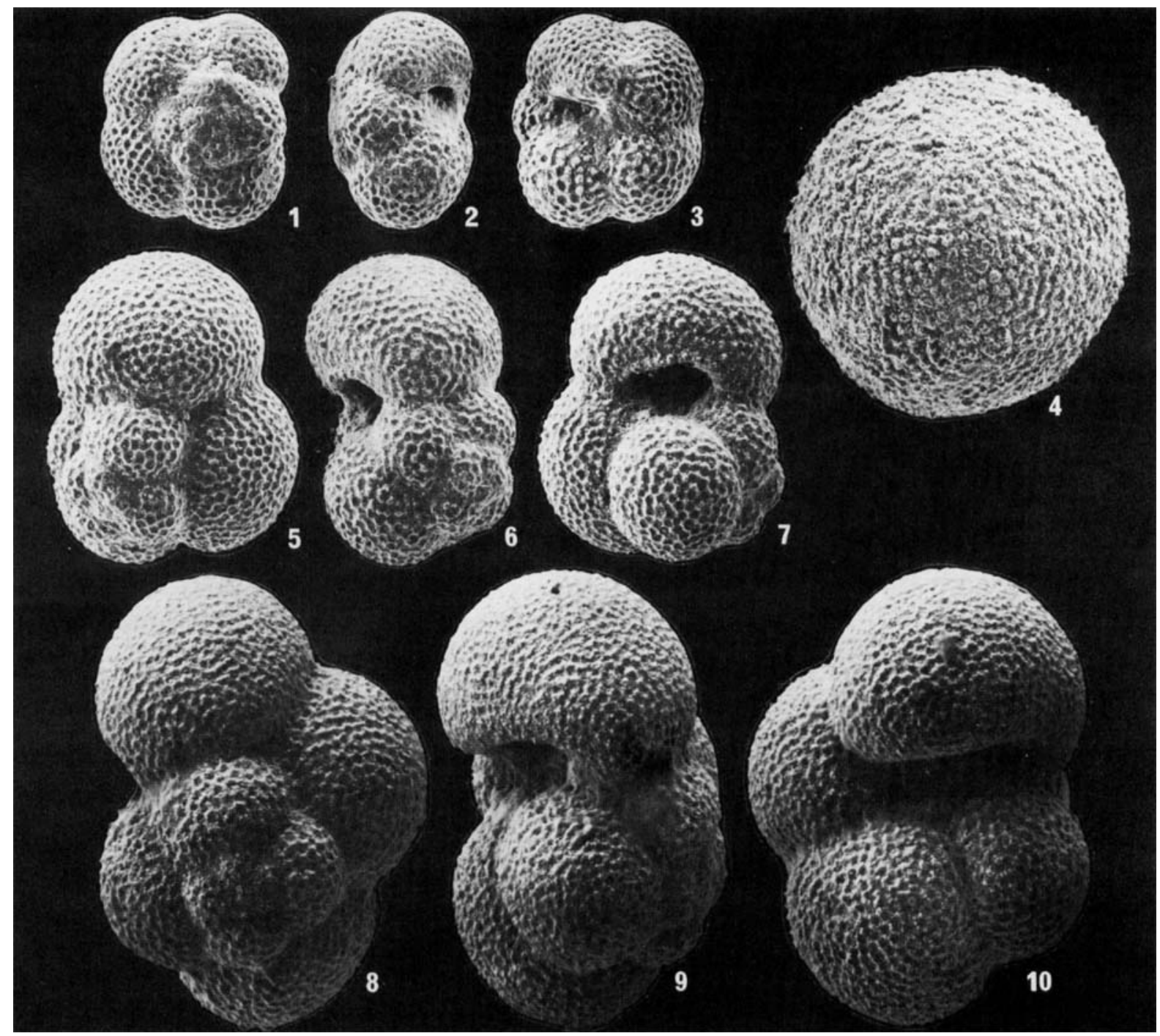

Explanation of Plate 2

All specimens are $\times 125$

Figs. 1-3. Neogloboquadrina pachyderma (Ehrenberg). Spiral, edge and umbilical views, P 51980. From Ramsholt Cliff.

Fig. 4. Orbulina universa d'Orbigny. P 51981. From Gedgrave Cliff.

Figs. 5-10. Neogloboquadrina atlantica (Berggren): figs. 5-7, spiral, edge and umbilical view of a high-spired individual, P 51982; figs. 8-10, spiral, edge and umbilical views, P 51983. Both from Sutton Knoll. 
lower diversity, even with a southern connection. The abscence of some of the deeper water species, such as Globorotalia scitula (Brady) in the Coralline Crag can be explained by its shallow water origin.

Of the nine species found in the Coralline Crag, three of them, namely Globorotalia puncticulata (Deshayes), Neogloboquadrina atlantica (Berggren) and $N$. humerosa (Takayanagi \& Saito), are extinct. According to Bé (1977), the remaining six species live today within the Transitional Faunas Provinces, with the surface water temperature range of $10-18^{\circ} \mathrm{C}$.

\section{AGE AND CORRELATION}

At DSDP Site 410 (Fig. 2), Globorotalia puncticulata (Deshayes) first appeared in the lower part of the Early Pliocene (Poore, 1978) where its range overlaps that of G. conomiozea Kennett, its immediate ancestor in the S. W. Pacific, according to Malmgren \& Kennett (1981). Further north at DSDP Sites 407 and 408 (Fig. 2), G. puncticulata made a later entry in the Early Pliocene and is unaccompanied by its immediate ancestor (Poore, 1978). Since it makes a cryptogenic appearance, it is therefore reasonable to infer that its entry into the North Sea may have been at a similar time to, or even later than at Sites 407 and 408 (assuming the connection to the North Atlantic was via the northern entrance to the North Sea). If this is accepted the placing of the entry of $G$. puncticulata into the North Sea at the Miocene/Pliocene boundary by King (1983) is probably too early.

Weaver (1986), having examined the planktonic foraminifera of DSDP Sites 606 and 611 (Leg 94), considers that $G$. puncticulata appeared for the first time in the North Atlantic in the Early Pliocene at c. 4.2 $\mathrm{Ma}$ and that it became extinct just before the first appearance of its descendent species, $G$. inflata (d'Orbigny) (Table 2). Poore (1978) showed a long overlap in the ranges of these two species at Site 410 and a possible short overlap at the more northern Site 408 and no overlap at Site 407.

Hooper \& Funnell (1986) also recorded . . . "an apparent and very rapid transition between these two species, at around 2.3 Ma" at DSDP Site 552A (Fig. 2) which is at lat. $56^{\circ} \mathrm{N}$ in the North Atlantic, but later concluded that the first appearance of $G$. inflata was caused by its migration and not by its direct evolution from $G$. puncticulata. Further south at DSDP Site 548 (Fig. 2) at lat. $48^{\circ} \mathrm{N}$, Loubere \& Jakiel (1985) concluded that there was an evolutionary transition between the two species, although their stratigraphic range chart for the site shows the overlap only occurring in one sample. Whereas Poore (1978) recorded the first appearance of $G$. inflata with the first ice-rafted material in the North Atlantic, dated by Shackleton et al. (1984) at $2.4 \mathrm{Ma}$, Weaver \& Clement (1986) are of the opinion that $G$. inflata appeared in the Late Pliocene at about 2.0-2.2 Ma, with the extinctions of G. puncticulata and N. atlantica occurring at 2.2-2.4 $\mathrm{Ma}$ and 2.3-2.4 Ma, respectively; we used the first figure in each case in Table 2.

Hodgson \& Funnell (1986) have recently reported the occurrence of the (?) planktonic algal cyst, Bolboforma costata Murray, in a sample of Coralline Crag taken from an excavation near Ramsholt Cliff. This fossil is so far only recorded in the nannofossil Zone NN15 (i.e. between c. 3.5 and 3.4 Ma) (Murray, 1984) and it seems probable that the Coralline Crag itself represents only the early part of the joint range of $G$. puncticulata and $N$. atlantica.

\section{CONCLUSIONS}

The Coralline Crag deposits were laid down during the Pliocene within the joint ranges of $G$. puncticulata and $N$. atlantica (c. 4.2 to $2.3 \mathrm{Ma}$ ); other evidence (Hodgson \& Funnell, 1986) suggests that the deposits are mostly Early Pliocene in age, probably no younger than c. $3.4 \mathrm{Ma}$.

As far as we can judge, all our samples containing planktonic foraminifera, including the Gedgrave Cliff samples taken from an excavation at the base of the section, are referable to Facies A - relatively low energy deposits underlying the higher energy, more generally exposed, sand-wave facies (Hodgson \& Funnell, 1986) of the Coralline Crag. Tidal currents in the southern North Sea Basin may have been less strong and a southwestern connection with the North Atlantic may have been less well developed then than during later Coralline and Red Crag times. In any case the low planktonic foraminiferal species diversity indicates a rather remote connection with the open ocean waters of the North Atlantic. The planktonic foraminifera

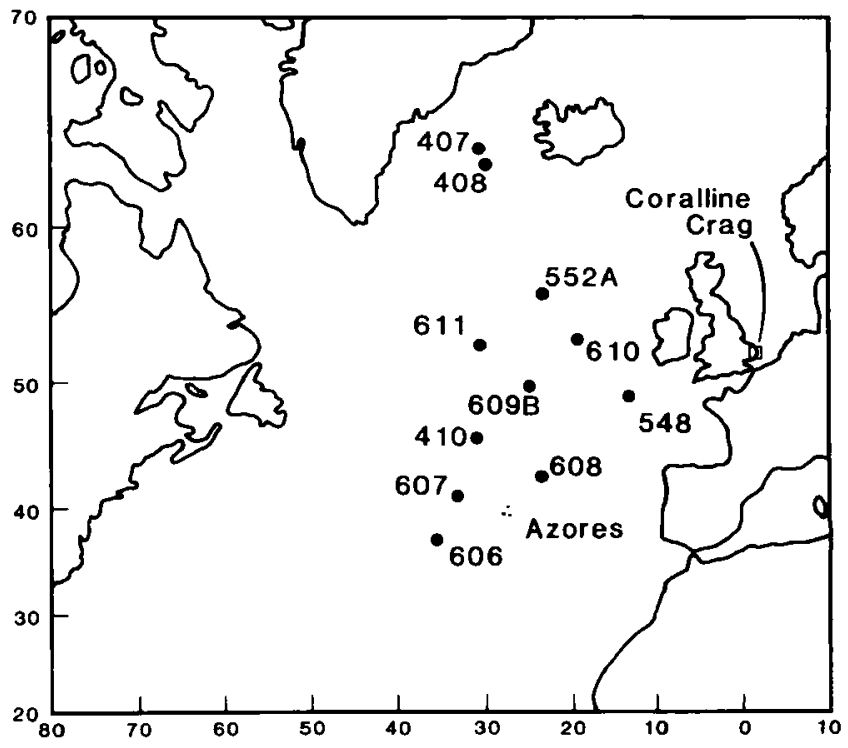

Fig. 2 Map of the North Atlantic showing location of DSDP Sites mentioned in the text and the Coralline Crag. 
suggest surface water temperatures in the range $10-18^{\circ}$ C.

\section{ACKNOWLEDGEMENTS}

We are grateful to Dr. P. P. E. Weaver (Institute of Oceanographic Sciences, Wormley) for the loan of the DSDP Site 609B samples and for both his and Mr. P. W. Hooper's (University of East Anglia, Norwich) comments on the manuscript. Dr. N. J. Morris (British Museum (Natural History), London) kindly provided the Ramsholt sample. Mr. J. Taylor (Open University) drafted Fig. 2 and Table 2.

\section{Manuscript received January 1987 \\ Revised manuscript accepted June 1987}

\section{REFERENCES}

Andrew, R. \& West, R. G. 1977. Pollen spectra from Pliocene Crag at Orford, Suffolk. New Phytol., 78, 709-714.

Banner, F. T. \& Blow, W. H. 1960. Some primary types of species belonging to the superfamily Globigerinacea. Contr. Cushman Fdn. foramin. Res., 11, 1-41, pls. 1-8.

Bé A. W. H. 1977. An ecological, zoogeographic and taxonomic review of Recent planktonic foraminifera. In Ramsay, A. T. S. (Ed.), Oceanic Micropalaeontology, 1, 1-100, pls. 1-12. Academic Press, London.

Berggren, W. A. 1972. Cenozoic biostratigraphy and paleobiogeography of the North Atlantic. Init. Repts. Deep Sea Drilling Project, 12, 965-1001, pls. 1-13.

Berggren, W. A., Kent, D. V. \& Van Couvering, J. A. 1985. The Neogene: Part 2. Neogene geochronology and chronostratigraphy. In Snelling, N. J. (Ed.), Geochronology and the stratigraphic record. Mem. geol. Soc. Lond., 10, 211-260.

Bolli, H. M. 1957. Planktonic foraminifera from the OligoMiocene Cipero and Lengua Formations of Trinidad, $B$. W. I. Bull. U.S. Natn. Mus., 215, 97-123, pls. 22-29.

Bolli, H. M. \& Saunders, J. B. 1985. Oligocene to Holocene low latitude planktic foraminifera. In Bolli, H. M., Saunders, J. B. \& Perch-Nielsen, K. (Eds.), Plankton stratigraphy, 155-262, figs. 1-45. Cambridge Univ. Press.

Brady, H. B. 1884. Report on the Foraminifera dredged by H.M.S. Challenger during the years 1873-1876. Rep. Scient. Results Voy. Challenger (Zool.), 9, 1-814, pls. $1-115$.

Carter, D. J. 1951. Indigenous and exotic foraminifera in the Coralline Crag of Sutton, Suffolk. Geol. Mag., 88, 236248.

Carter, D. J. 1957. The distribution of the foraminifer Alliatina excentrica (di Napoli Alliata) and the new genus Alliatinella. Palaeontology, 1, 76-86, pl. 14.

Curry, D., Adams, C. G.. Boulter. M. C., Dilley, F. C.. Eames, F. E., Funnell, B. M. \& A. Wells, M. K. 1978. A correlation of the Tertiary rocks of the British Isles. Spec. Rep. geol. Soc. Lond., 12, 1-72.

Deshayes, G. P. 1832. Encyclopédie méthodique. Histoire naturelle des Vers, vol. 2 (with suppl.), 594pp.. Mme. V. Agasse. Paris

Doppert, J. W. C. 1985. Foraminifera of the Coralline Crag of Suffolk. Bull. geol. Soc. Norfolk, 35. 47-52.
Egger, J. G. 1893. Foraminiferen aus Meeresgrundproben, gelonthet von 1874 bis 1876 von. S. M. Sch. Gazelle. Abh. bayer. Akad. Wiss., 18(2), 1-166 (193-458), pls. 1-21.

Ehrenberg, C. G. 1861. Elemente des tiefen Meeresgrundes im Mexikanischem Golfstrome bei Florida; über die Tiefgrund-Verhältnisse des Oceans am Eingange der Davisstrasse und bei Island. Mber. K. preuss. Akad. Wiss., 1861, 275-315.

Ehrenberg, C. G. 1873. Mikrogeologische Studien über das kleinste Leben der Meeres-Tiefgründe aller Zonen und dessen geologische Einfluss. Phys. Math. Abh. K. Akad. Wiss. Berlin, 1872, 131-397, pls. 1-12.

Hodgson, G. E. \& Funnell, B. M. 1986. Foraminiferal biofacies of the Early Pliocene Coralline Crag. In Hart, M. B. (Ed.), Carbonate Micropalaeontology, pp. 44-73, pls. 3.1-3.2. Ellis Horwood Ltd, Chichester, for British Micropalaeontological Society.

Holmes, N. A. 1984. An emendation of the genera Beella Banner \& Blow, 1960, and Turborotalita Blow \& Banner, 1962, with notes on Orcadia Boltovskoy and Watanabe, 1982. J. foramin. Res., 14, 101-110, pls. 1-3.

Hooper, P. W. P. \& Funnell, B. M. 1986. Late Pliocene to Recent planktonic foraminifera from the North Atlantic (DSDP Site 552A): quantitative palaeotemperature analysis. In Summerhayes, C. P. \& Shackleton, N. J. (Eds.), North Atlantic Palaeoceanography. Spec. Publ. geol. Soc. Lond., 21, 181-190.

Hughes, M. \& Jenkins, D. G. 1981. Neogene. In Jenkins, D. G. \& Murray. J. W. (Eds.), Stratigraphic Atlas of Fossil Foraminifera, 268-285, pls. 9.1-9.3. Ellis Horwood Ltd, Chichester, for British Micropalaeontological Society.

Jenkins, D. G. 1966. Planktonic foraminiferal zones and new taxa from the Danian to Lower Miocene of New Zealand. N.Z. Jl Geol. Geophys. 8, 1088-1123, figs. 1-15.

Jenkins, D. G. 1967. Planktonic foraminiferal zones and new taxa from the Lower Miocene to Pleistocene of New Zealand. N.Z. Jl Geol. Geophys., 10, 1064-1078, figs. 1-4.

Jenkins, D. G. 1975. Cenozoic planktonic foraminiferal biostratigraphy of the southwestern Pacific and Tasman Sea - DSDP Leg 29. Init. Repts. Deep Sea Drilling Project, 29, 449-467.

Jenkins, D. G. \& Orr, W. N. 1972. Planktonic foraminiferal biostratigraphy of the eastern equatorial Pacific - DSDP Leg 9. Init. Repts. Deep Sea Drilling Project, 9, 1060-1193, pls. $1-41$

Jenkins, D. G., Whittaker, J. E. \& Carlton, R. 1986. On the age and correlation of the St. Erth Beds, S. W. England, based on planktonic foraminifera. J. micropalaeontol., 5, 93-105, pls. 1, 2.

Jones, T. R., Parker, W. K. \& Brady, H. B. 1866. A monograph of the Foraminifera of the Crag, Part 1. Palaeontogr. Soc. (Monogr.), 1865, 1-71, pls. 1-4.

Kennett, J. P. \& Srinivasan, M. S. 1980. Surface ultrastructural variation in Neogloboquadrina pachyderma (Ehrenberg): phenotypic variation and phylogeny in the Late Cenozoic. In Sliter, W. V. (Ed.). Studies in Marine Micropaleontology. A Memorial Volume to Orville L. Bandy. Spec. Publs Cushman Fdn., 19, 134-162, pls. 1-8.

Kennett, J. P. \& Srinivasan, M. S. 1983. Neogene planktonic foraminifera, a phylogenetic atlas. 265pp., 61pls. Hutchinson Ross Publ. Comp.. Stroudsburg.

King, C. 1983. Cainozoic micropalaeontological biostratigraphy of the North Sea. Rep. Inst. geol. Sci., 82/7, 1-40. pls. $1-6$. 
Loubere, P. \& Jakiel, R. 1985. A sedimentological, faunal, and isotopic record of Middle-to-Late Pliocene transition in the Northeastern Atlantic, Deep Sea Drilling Project Site 548. Init. Repts. Deep Sea Drilling Project, 80, 473-488, pls. 1,2 .

Malmgren, B. A. \& Kennett, J. P. 1981. Phyletic gradualism in a Late Cenozoic planktonic foraminiferal lineage, DSDP Site 284: southeast Pacific. Paleobiol., 7, 230-240.

Murray, J. W. 1984. Biostratigraphic value of Bolboforma, Leg 81, Rockall Plateau. Init. Repts. Deep Sea Drilling Project, 81, 535-539, pl. 1.

Mathers, S. J., Zalasiewicz, J. A. \& Balson, P. S. 1984. A guide to the geology of south-east Suffolk. Bull. geol. Soc. Norfolk, 34, 65-101.

Natland, M. L. 1938. New species of foraminifera from off the west coast of North America and from the later Tertiary of the Los Angeles Basin. Bull. Scripps Instn. Oceanogr. tech. Ser., 4, 137-152, pls. 3-7.

Orbigny, A. D. d' 1826 . Tableau méthodique de la classe des Cephalopodes. Annls Sci. nat., ser. 1, 7, 96-169, 245-314, pls. $10-17$

Orbigny, A. D. d' 1839. Foraminifères. In Sagra, R. de la, Histoire physique, politique et naturelle de l'Ile de Cuba, 1-224, pls. 1-12. A. Bertrand, Paris.

Parker, F. L. 1962. Planktonic foraminiferal species in Pacific sediments. Micropalaeontology, 8, 219-254, pls. 1-10.

Pomerol, C. 1982. The Cenozoic Era. Tertiary and Quaternary. 272pp. Ellis Horwood Ltd, Chichester.

Poore, R. 1978. Oligocene through Quaternary planktonic foraminiferal biostratigraphy of the North Atlantic: DSDP Leg 49. Init. Repts. Deep Sea Drilling Project, 49, 447-517, pls. $1-20$.

Poore, R. \& Berggren, W. A. 1974. Pliocene biostratigraphy of the Labrador Sea: calcareous plankton. J. foramin. Res., 4, 91-108, pls. 1-3.

Prestwich, J. 1871. On the structure of the Crag-beds of Suffolk and Norfolk with some observations on their organic remains. 1. The Coralline Crag of Suffolk. $Q . J l$. geol. Soc. Lond., 27, 115-146.

Scott, G. H. 1980. Globorotalia inflata lineage and $G$. crassaformis from Blind River, New Zealand, recognition, relationship and use in latest Miocene-Early Pliocene biostratigraphy. N.Z. Jl Geol. Geophys., 23, 665-677, figs. $1-7$.

Shackleton, N. J., Backman, J., Zimmerman, H., Kent, D. V., Hall, M. A., Roberts, D. G., Schnitker, D., Baldauf, J. G., Desprairies, A., Homighousen, R., Huddleston, P. F., Keene, J. B., Kaltenback, A. J., Krumsiek, K. A. O., Morton, A. C., Murray, J. W. \& Westburg-Smith, J. 1984. Oxygen isotope calibration of the onset of ice rafting and history of glaciation in the North Atlantic region. Nature, 307, 620-623.

Soldani, A. 1791. Testaceographiae ac Zoophytographiae parvae et microscopiae. 1(2), 87-200, pls. 94-142. Senis (Sienna).

Srinivasan, M. S. \& Kennett, J. P. 1976. Evolution and phenotypic variation in the late Cenozoic Neogloboquadrina dutertrei plexus. In Takayanagi, Y. \& Saito, T. (Eds.), Progress in Micropalaeontology. Micropalaeontology Spec. Publ., 2, 329-355, pls. 1-8.

Takayanagi, Y. \& Saito, T. 1962. Planktonic foraminifera from the Nobori Formation, Shikoku, Japan. Sci. Rep. Tókoku Univ., ser. 2 (Geol.). 5, 67-106, pls. 24-28.
Weaver, P. P. E. 1986. Late Miocene to Recent planktonic foraminifera from the North Atlantic: DSDP Leg 94. Init. Repts. Deep Sea Drilling Project, 94, 703-727, pls. 1-3.

Weaver, P. P. E. \& Clement, B. M. 1986. Magnetobiostratigraphy of planktonic foraminiferal datums: DSDP Leg 94, North Atlantic. Init. Repts. Deep Sea Drilling Project, 94, 815-829.

Wiesner, H. 1931. Die Foraminiferen. Dt. Südpol.-Exped., 20: 53-165, pls. 1-24.

Wilkinson, I. P. 1980. Coralline Crag ostracods and their environmental and stratigraphic significance. Proc. Geol. Ass., 91, 291-306, pls. 1, 2. 